JINoP
PINoP (Jurnal Inovasi Pembelajaran)
Polume 7, Nomor 2, November 2021, pp. 167-177
http:///ejournal.umm.ac.id/index.php/jinop

\title{
Peningkatan kompetensi guru dalam penggunaan media tablet BOS afirmasi di SMA Negeri 3 Kundur Kepulauan Riau
}

\author{
Memme Nini ${ }^{1)^{*}}$ \\ ${ }^{1}$ SMA Negeri 3 Kundur, Jalan Besar Sungai Ungar Tanjungbatu Kundur, Karimun, Indonesia. \\ memmenini@gmail.com* \\ *Penulis Koresponden
}

\begin{abstract}
ABSTRAK
Proses belajar mengajar saat ini dilakukan secara daring menyulitkan sebagian besar guru yang hanya bisa menggunakan What'sApp dalam proses belajar dari rumah. Selain itu, guru-guru juga mengalami masalah keterbatasan ilmu pengetahuan tentang media pembelajaran online serta kapasitas gawai/ memori gawai. Tujuan dari penelitian ini adalah untuk mendeskripsikan pemanfaatan tablet BOS Afirmasi oleh guru melalui workshop. Penelitian ini merupakan penelitian deskriptif dengan jenis penelitian tindakan sekolah. Penelitian ini dilakukan di SMA Negeri 3 Kundur setelah dikeluarkannya surat dari gubernur Kepulauan Riau tertanggal 16 Maret 2020 tentang kegiatan belajar mengajar yang dilakukan secara daring. Data dikumpulkan melalui wawancara, observasi, dan dokumentasi. Teknik analisis data yang digunakan adalah teknis Miles dan Huberman, yang terdiri dari tahap reduksi data, display data, dan verifikasi data.. Hasil penelitian menunjukkan bahwa setelah workshop, guru-guru mampu menggunakan Google Classroom sehingga proses belajar mengajar dari rumah sudah berjalan lancar, begitu pula dalam proses penilaian harian. Sebagian guru juga telah menggunakan aplikasi Telegram dan sudah bisa menggunakan aplikasi Zoom dengan baik, sehingga banyak guru yang mengikuti pelatihan daring melalui aplikasi tersebut.

Kata Kunci: Tablet BOS Afirmasi; Workshop; Kompetensi Guru; Media Pembelajaran Daring.
\end{abstract}

\section{ABSTRACT}

This research was conducted at SMA Negeri 3 Kundur following the policy from the governor of Kepulauan Riau on March 16, 2020 about online teaching and learning activities. It was shown that most teachers only used What's App due to their limited knowledge about online learning media and the capacity of their devices. This study aims to describe the use of BOS Tablets Afirmasi by teachers. Descriptive approach was employed with school action research through series of workshops. The data was collected through interviews, observation, and documentation. The obtained data was analyzed through Milles and Huberman technique consisting of data reduction, data display, and data verification. Results showed that teachers could Google Classroom after the workshops, in which online learning and daily assessment process ran more smoothly. Some teachers have also used Telegram and Zoom well where they were also taking online training through those applications.

Keywords: BOS Tablet Afirmasi; Workshop; Teacher Competence; Online Learning Media.

diunggah: 2021/08/04, direvisi: 2021/11/29, diterima: 2021/11/30, dipublikasi: 2021/11/30

Copyright (c) 2021 Memme Nini

This is an open access article under the CC-BY license

Cara sitasi: Nini, M. (2021). Pemanfaatan Tablet BOS Afirmasi Peningkatan kompetensi guru dalam penggunaan media tablet bos afirmasi di SMA Negeri Kundur Kepulauan Riau. JINoP (Jurnal Inovasi Pembelajaran), 7(2). https://doi.org/10.22219/jinop.v7i2.17654 


\section{PENDAHULUAN}

Kecakapan, kelaziman, perilaku dalam diri yang diharapkan mampu membuat seseorang menjadi lebih baik dapat dikembangkan melalui suatu metode yaitu pendidikan (Ulfah Fajarini, 2014). Mengacu pada UU SISDIKNAS No. 20 tahun 2003, bahwa pendidikan pada hakikatnya adalah sebuah upaya terstruktur untuk mengembangkan dan meningkatkan kemampuan peserta didik guna mencapai kecerdasan, keterampilan dan pembentukan budi pekerti. Dalam hal ini, pendidikan harus benar-benar direncanakan dengan matang agar lingkungan belajar siswa senantiasa aktif, kreatif dan inovatif dengan tetap memiliki kepribadian yang berlandaskan nilai- nilai keagamaan (Nadlir, 2014).

Berdasarkan instruksi dari Gubernur Kepulauan Riau tertanggal 16 Maret 2020 Nomor 440/ 449/DISDIK-ET/2020, untuk mencegah penyebaran virus corona selama pandemic, agenda pembelajaran pada tiap-tiap sekolah sementara waktu tidak dilanjutkan. Kegiatan tatap muka tersebut terhitung minggu ketiga Maret 2020 hingga akhir Maret 2020, di mana satuan pendidikan tetap melaksanakan kegiatan belajar dari rumah secara virtual melalui platform elearning di sekolahnya masing-masing kecuali siswa-siswi yang duduk di kelas XII. Mereka tetap mengikuti pelaksanaan evaluasi pembelajaran pada Ujian Nasional Tahun 2020 yang telah diatur oleh Badan Standar Nasional Pendidikan (BSNP).

Dari surat edaran tersebut, peserta didik diminta untuk tetap belajar meskipun tidak berada di sekolah. SMA Negeri 3 Kundur melakukan proses belajar mengajar melalui media sosial. Media yang digunakan rata-rata guru di SMA Negeri 3 Kundur adalah What'sApp. Dari 29 orang guru, 16 di antaranya sudah menggunakan media google classroom namun belum secara maksimal; dan dari 29 orang guru, 13 diantaranya belum menggunakan google classroom karena keterbatasan ilmu pengetahuan mengenai media pembelajaran online dan kapasitas gawai yang dimiliki.

Semenjak proses belajar dari rumah berlangsung, gawai yang dimiliki oleh guru sering mengalami masalah karena banyaknya tugas siswa yang masuk ke memori gawai. Ada beberapa guru yang selalu mengikuti perkembangan teknologi yang berkaitan dengan pendidikan, misalnya dalam penggunaan beberapa media penunjang proses pembelajaran. Semua ini memerlukan aplikasi yang harus diunduh. Namun kapasitas gawai yang terbatas membuat para guru tersebut tidak dapat menggali ilmu lebih mendalam. Padahal dalam proses pembelajaran diperlukan adanya komunikasi yang aktif antara guru dan siswa (Habibah et al., 2020; Afnibar \& Fajhriani, 2020), karena keberhasilan dalam proses pembelajaran itu dapat dilihat dari pemahaman guru tentang konsep, penguasaan materi, dan faktor ketepatan penggunaan media pembelajaran (Faiz \& Kurniawaty, 2020).

Pada awal tahun 2020 SMA Negeri 3 Kundur mendapat bantuan tablet afirmasi dari pemerintah pusat. Mengingat adanya permasalahan guru-guru mengenai proses pembelajaran daring yang tidak terlaksana secara maksimal dan salah satu penyebabnya adalah kapasitas gawai yang dimiliki maka sekolah memberikan bantuan berupa peminjaman tablet afirmasi kepada setiap guru. Dengan harapan guru-guru dapat memanfaatkannya untuk proses belajar dari rumah oleh guru kepada siswa. Setelah guru diberikan peminjaman tablet tersebut, peneliti sebagai pemimpin di sekolah ini mengadakan workshop pemanfaatan 
tablet afirmasi untuk peningkatkan kompetensi guru selama pembelajaran daring bagi siswa di SMAN 3 Kundur Tahun 2020.

Tablet afirmasi merupakan tablet yang diperoleh dari pemerintah yang diatur dalam "Peraturan Menteri Pendidikan dan Kebudayaan Republik Indonesia Nomor 31 Tahun 2019 Pasal 2 Ayat 1 yang berbunyi bahwa pemberian BOS Afirmasi bertujuan untuk membantu peningkatan mutu pembelajaran pada satuan pendidikan dan menengah yang diselenggarakan oleh pemerintah di daerah tertinggal, terdepan dan terluar".

Salah satu kegiatan yang akan dilakukan dalam upaya peningkatan kompetensi guru di SMA Negeri 3 Kundur adalah workshop. Muslihudin (2016) menyatakan bahwa dunia edukasi tak lepas dari perlunya diadakan pelatihan dimana dalam kegiatan tersebut kita dapat terus belajar, saling berbagi saran dan masukan saling memberi ide dan menerima tanggapan yang berlandaskan jiwa kebersamaan dan gotong royong. Workshop merupakan pertemuan dari beberapa orang seprofesi yang melakukan kegiatan belajar (pelatihan) untuk mengetahui sesuatu hal (Mockler, 2013). Notoatmodjo (2005) dalam Sa'bani (2017), menambahkan bahwa pelatihan bertujuan untuk mengingkatkan pengetahuan dan keterampilan sebagai inti keberhasilan program pendidikan.

Pada penelitian ini kegiatan workshop dilakukan oleh peneliti untuk memfasilitasi guru dalam belajar menggunakan media pembelajaran daring yang akan diterapkan kepada siswa sebagai respon adanya pembelajaran daring ini. Sehingga dengan adanya kegiatan workshop atau pelatihan ini akan memberikan pengalaman pada guru karena hal ini merupakan faktor yang paling berpengaruh dalam peningkatan kompetensi dan profesionalisme guru bidang studi. Sehingga guru perlu melakukan peningkatan kompetensinya termasuk dalam hal penggunaan media pembelajaran.

Ditambah pula sebagai seorang pendidik kita harus mampu membuat perencanaan yang matang, dapat berinteraksi dengan peserta didik melalui pengelolaan kelas yang sempurna supaya tujuan pembelajaran yang diharapkan dapat tercapai. Namun di lapangan masih ada kita temukan pengajar yang belum mampu menerapkan kompetensi pedagogiknya secara maksimal (Sadewo \& Purnasari, 2019). Khususnya, keahlian dalam menguasai teknologi dan menggunakannya dalam pembelajaran terutama pada penggunaan media pembelajaran daring, sebab fungsi media akan dapat tersampaikan sesuai dengan pesan yang dimaksud. Sehingga adanya pandangan penggunaan media yang tepat akan berpengaruh pada pemanfaatan guru dalam penggunaan media yang dimaksud (Budiyono, 2020; Habibah et al., 2020).

Media pembelajaran daring atau online ini sebenarnya merupakan pembelajaran berbasis teknologi. Seperti yang dikatakan oleh Tarlia Nalar (2020) bahwa pembelajaran berbasis teknologi ini tidaklah sulit, hanya saja kita sebagai guru haruslah jeli dengan kebiasaan peserta didik dan pola hidupnya. Di sini dijelaskan bahwa guru harus bisa menggunakan teknologi untuk proses pembelajaran, seperti pada masa pandemi ini guru memang dituntut untuk mengunakan media online. Perkembangan teknologi informasi pada masa ini secara tidak langsung membuat para guru harus dapat memanfaatkannya dalam pembelajaran. Sehingga adanya pengintegrasian teknologi dan informasi dalam proses pembelajaran menjadikan guru sebagai fasilitator, kolabolator, mentor, dan teman belajar bagi peserta didik (Myori E.D, Krismadinata, 2019). 
Media pembelajaran daring pada umumnya dilakukan dengan bantuan teknologi yaitu dengan bantuan gawai atau laptop. Dengan adanya akses internet pembelajaran daring menjadi semakin mudah, dapat menghubungkan guru dengan siswa dan siswa antar siswa secara fleksibel, dan mampu menghadirkan berbagai macam interaksi pembelajaran (Sadikin \& Hamidah, 2020). Media pembelajaran saat ini telah maju dan berkembang seiring dengan munculnya revolusi komunikasi yang dimanfaatkan dalam mencapai tujuan pembelajaran.

Sebagaimana disampaikan juga oleh Habibah et al (2020) bahwa pada saat ini untuk mengefektifkan proses pembelajaran mulai dari guru yang mendidik siswa-siswi di bangku SD, SLTP, SLTA hingga dosen yang mengajar di Perguruan Tinggi telah banyak menggunakan media pembelajaran dalam bentuk platform/ program seperti; E-Learning, Zoom, Google meet, Google Classroom, YouTube, WAG, Edmodo, dan berbagai platform lainnya. Akan tetapi pemanfaatan teknologi dalam perkembangan dunia pendidikan di Indonesia belumlah menyeluruh, dikarenakan masih banyaknya wilayah Indonesia yang tergolong daerah tertinggal dan terpencil menjadi penyebabnya. Hal ini menunjukkan adanya ketidakseimbangan antara daerah perkotaan dan daerah terpencil serta tertinggal dalam pemanfaatan teknologi guna menunjang proses pembelajaran (Reflianto \& Syamsuar, 2018).

Oleh karena itu, perlu kiranya untuk memberikan penguatan-penguatan akademik khususnya pada kompetensi guru agar selama pandemi ini dapat merespon berbagai perubahan yang terjadi dalam dunia pendidikan, khususnya pada masa Covid-19. Berangkat dari hal inilah, perlu dilakukan pembenahan kompetensi guru tentang pemanfaatan tablet afirmasi melalui workshop dalam upaya peningkatan kompetensi guru dalam penggunaan media pembelajaran daring bagi siswa di SMAN 3 Kundur Tahun 2020.

\section{METODE}

Penelitian ini menggunakan penelitian tindakan kelas melalui desain rancangan Kemmis dan Mc Taggart (1997) dalam Mahmud (2008) yang terdiri dari empat tahapan, yakni: perencanaan, pelaksanaan, pengamatan/ evaluasi dan refleksi (Wardani, 2007). Penelitian ini dilaksanakan dalam dua siklus. Indikator keberhasilan dalam penelitian tindakan ini adalah $80 \%$ pendidik mampu mengaplikasikan media whatssapp, google classroom, google form, telegram, dan zoom.

Subjek Penelitian Tindakan Sekolah (PTS) ini adalah guru-guru di SMA Negeri 3 Kundur Kabupaten Karimun yang berjumlah 29 orang. Penelitian ini dilakukan pada bulan Juli hingga Oktober 2020.

Teknik pengumpulan data diperoleh melalui data kualitatif, berupa:

1. Wawancara, wawancara dilakukan kepada guru-guru yang terlibat dalam workshop untuk mendapatkan data yang terkait dengan hasil pemanfaatan media tablet BOS Afirmasi dalam proses pembelajaran.

2. Observasi, digunakan untuk melengkapi data dari wawancara tentang masalah yang akan diteliti, yaitu pada saat pra siklus, siklus I, siklus II.

3. Dokumentasi, dokumentasi yang digunakan terkait dengan kegiatan workshop, media yang digunakan oleh guru pada proses belajar mengajar, dan dokumendokumen lainnya yang digunakan pada Penelitian Tindakan Sekolah (PTS) ini selama penelitian berlangsung. 
Analisis data dilakukan dengan menggunakan model analisis Miles dan Huberman yang terdiri dari tahap reduksi data, display data, dan verifikasi data. Dalam hal ini data akan disampaikan dalam bentuk tabel dan narasi untuk memperkuat pemahaman.

\section{HASIL DAN PEMBAHASAN}

Penelitian Tindakan Kelas dalam artikel ini dilakukan sesuai dengan rancangan Kemmis dan Mc Taggart yang terdiri atas empat langkah, yakni: perencanaan, pelaksanaan, pengamatan/ evaluasi dan refleksi. Pelaksanaan penelitian ini dilakukan dengan tiga tahap, yaitu pra siklus, siklus I dan siklus II.

\section{Pra-siklus}

Pada kegiatan pra-siklus, peneliti mengamati media pembelajaran yang dilaksanakan secara daring/ online. Pada awal pandemik ini guru telah menggunakan media pembelajaran daring/ online namun kompetensi guru dalam menggunakan media tersebut masih sangat rendah.

Berdasarkan hasil observasi dihasilkan bahwa kompetensi penggunaan media pembelajaran daring yang guru gunakan dapat dilihat pada tabel berikut:

Tabel 1. Kompetensi Guru dalam Penggunaan Media Pembelajaran Daring

\begin{tabular}{lccc}
\hline & $\begin{array}{c}\text { Media online } \\
\text { yang pernah } \\
\text { digunakan oleh } \\
\text { guru }\end{array}$ & $\begin{array}{c}\text { Media pembelajaran yang } \\
\text { digunakan oleh guru } \\
\text { dalam proses BDR }\end{array}$ & $\begin{array}{c}\text { Media Pembelajaran } \\
\text { yang telah dikuasai } \\
\text { oleh guru }\end{array}$ \\
\hline WhatsApp & $100 \%$ & $100 \%$ & $100 \%$ \\
Google Classroom & $55 \%$ & $66 \%$ & $21 \%$ \\
Google Form & $28 \%$ & $7 \%$ & $17 \%$ \\
Telegram & $31 \%$ & $0 \%$ & $10 \%$ \\
Zoom & $14 \%$ & $0 \%$ & $14 \%$ \\
\hline
\end{tabular}

Berdasarkan data di atas, kompetensi guru dalam penggunaan media pembelajaran daring sangatlah rendah. Hal ini dapat mempengaruhi proses belajar dari rumah (BDR) terhadap peserta didik, karena dalam proses pembelajaran daring guru harus dapat menggunakan media pembelajaran yang tepat sehingga peserta didik termotivasi untuk tetap belajar. Ulasan ini sesuai dengan Barni et al. (2019) yang menyatakan bahwa kemahiran guru dan variasi media pembelajaran meningkatkan motivasi belajar siswa.

Adapun media pembelajaran yang digunakan oleh guru untuk proses belajar dari rumah (BDR) belum maksimal, hal ini merupakan suatu masalah yang harus segera diselesaikan, karena dapat membuat hasil belajar peserta didik rendah. Berdasarkan data hasil wawancara bersama para guru SMA Negeri 3 Kundur terdapat penyebab dari hal tersebut yaitu:

1. Rendahnya kompetensi guru dalam penggunaan media pembelajaran bagi peserta didik dikarenakan kurangnya informasi mengenai penggunaan media pembelajaran daring.

2. Guru mengalami kendala dalam fasilitas saat menggunakan media yang harus mengunduh beberapa aplikasi media pembelajaran daring tersebut karena ratarata gawai yang digunakan oleh guru berkapasitas rendah. 
Temuan wawancara ini sesuai dengan yang dikatakan oleh (Budiyono, 2020) di mana rendahnya kompetensi guru mempengaruhi performa mereka dalam kelas.

Adanya wabah covid-19 ini membuat pembelajaran masih akan terus dilakukan dari rumah dalam bentuk pembelajaran daring dengan alternatif memanfaatkan android sebagai media pembelajarannya (Ramdani et al., 2020). Sebagaimana ditambahkan oleh Moore, Dickson-Deane, \& Galyen (2011) dalam Firman \& Rahayu (2020) tentang pembelajaran online, yaitu pembelajaran yang menggunakan keberadaan internet yang nantinya akan menghasilkan berbagai jenis interaksi pembelajaran. Pembelajaran online ini dirasa sangat efektif untuk mencegah wabah Covid-19, akan tetapi di sisi lainnya juga memberikan persoalan baru bagi dunia pendidikan Indonesia, terutama pada ketidaksiapan guru dan murid dalam merespon adanya keadaan ini (Yuangga \& Sunarsi, 2020). Walaupun sebenarnya dalam pembelajaran online ini terdapat pengaruh positif untuk meningkatkan motivasi dan hasil belajar siswa (Mandailina et al., 2021).

Dari beberapa permasalahan tersebut maka peneliti sebagai pimpinan di sekolah ini meminjamkan tablet afirmasi selama proses pembelajaran daring dan mengadakan kegiatan workshop penggunaan media pembelajaran daring bagi peserta didik.

\section{Siklus I}

Siklus I diawali dengan tahap perencanaan yang terdiri atas:

1. Pelaporan kegiatan penelitian kepada Pengawas serta memohon izin penelitian. Hal ini termasuk berkoordinasi dan meminta masukan tentang masalah yang diteliti sekaligus membicarakan tentang teknis, waktu pelaksanaan penelitian dan hal-hal terkait dengan penelitian dan atau workshop pemanfaatan tablet afirmasi.

2. Menginformasikan kepada pengurus tablet bahwa akan dilakukan peminjaman tablet untuk guru mata pelajaran.

3. Memberikan informasi kepada guru-guru tentang kegiatan peminjaman tablet dan workshop.

4. Menyusun agenda workshop membuat media pembelajaran.

Pada tahap pelaksanaan di siklus I dilakukan empat kali kegiatan, yaitu: 1) peneliti bersama tim pengurus tablet memberikan peminjaman tablet kepada setiap guru dengan penandatangan surat perjanjian; 2) mengadakan kegiatan workshop dengan mengundang nara sumber dari luar; 3) pemantauan perkembangan guru dalam penggunaan media pembelajaran daring bagi peserta didik sesuai dengan ilmu yang telah didapat oleh guru pada kegiatan workshop yang telah dilakukan; dan 4) pengevaluasian kompetensi guru dalam penggunaan media pembelajaran daring dengan memanfaatkan tablet afirmasi yang telah dipinjamkan oleh pihak sekolah. Keempat tahap ini sesuai dengan

Pada tahap pengamatan, pengetahuan guru dalam penggunaan media pembelajaran daring bagi siswa ditinjau. Hal ini dimaksudkan untuk dapat memperbaiki kelemahan tersebut sehingga kegiatan pembinaan melalui workshop berjalan sesuai dengan tujuan untuk meningkatkan kompetensi peserta.

Adapun data kompetensi guru menggunakan media pembelajaran daring tersebut dapat dilihat pada tabel berikut. 
Tabel 2. Kompetensi Guru dalam Penggunaan Media Pembelajaran Daring pada kegiatan Siklus I

\begin{tabular}{lccc}
\hline & $\begin{array}{c}\text { Media } \text { online yang } \\
\text { pernah digunakan } \\
\text { oleh guru }\end{array}$ & $\begin{array}{c}\text { Media pembelajaran yang } \\
\text { digunakan oleh guru } \\
\text { dalam proses BDR }\end{array}$ & $\begin{array}{c}\text { Media Pembelajaran } \\
\text { yang telah dikuasai } \\
\text { oleh guru }\end{array}$ \\
\hline $\begin{array}{l}\text { WhatsApp } \\
\text { Google } \\
\text { Classroom } \\
\text { Google Form }\end{array}$ & $100 \%$ & $100 \%$ & $100 \%$ \\
Telegram & $100 \%$ & $100 \%$ & $66 \%$ \\
Zoom & $7 \%$ & $34 \%$ & $48 \%$ \\
\hline
\end{tabular}

Pada tahap refleksi, diketahui bahwa workshop pemanfaatan tablet meningkatkan kompetensi guru dalam penggunaan media pembelajaran daring, meskipun ada beberapa guru yang belum menguasai penggunaan google classroom/ telegram/ google form secara maksimal. Berdasarkan indikator keberhasilan tindakan yang ditetapkan, terlihat bahwa $100 \%$ guru mampu mengaplikasikan media whatsapp dan $86 \%$ guru mampu memanfaatkan media zoom. Hal ini dikarenakan kedua media ini tidak sulit dalam mengoperasikannya dan sudah tersedia di hp android milik guru dan siswa. Sementara itu, aplikasi google classroom, google form, dan telegram belum mencapai keberhasilan sesuai indikator yang ditetapkan. Hal ini dikarenakan ketiga aplikasi ini agak rumit dalam pengoperasiannya.

Di antara keahlian yang harus diperhatikan pendidik dalam proses belajar mengajar yaitu bagaimana menggunakan media pembelajaran. Menurut (MR, 2021), media pembelajaran saat ini merupakan sarana yang sangat penting. Memberikan hal nyata lewat gambar dan suara yang baik tidak dapat dipungkiri lagi media memudahkan guru dalam menyampaikan pesan atau materi pada peserta didik. Media pembelajaran yang dihadirkan diyakini memudahkan peserta didik dalam belajar.

Ketidaksesuaian antara teori belajar, pemilihan media belajar yang tidak sesuai sasaran dengan penerapannya tidak akan mendapatkan hasil yang maksimal (Sutirman, 2013), sehingga adanya media pembelajaran dengan beragam bentuk dan fungsinya harus disesuaikan dengan kebutuhan pembelajar agar lebih mudah dalam memahami materi (Puspita, 2020).

\section{Siklus II}

Tahap perencanaan pada siklus II dilakukan dengan memberikan bimbingan sebagai tindak lanjut dari workshop yang telah dilakukan pada siklus I. Selanjutnya, pertemuan dilakukan pada tahap pelaksanaan untuk membahas media pembelajaran daring, memfasilitasi guru untuk saling berbagi. Hal ini dilakukan untuk: 1) lebih mendalami penggunaan media pembelajaran daring dengan memanfaatkan tablet afirmasi sekolah; 2) memantau perkembangan guru dalam penggunaan media pembelajaran daring bagi peserta didik sesuai dengan ilmu yang telah didapatkan dalam workshop; dan 3) mengevaluasi kompetensi guru dalam penggunaan media pembelajaran daring dengan memanfaatkan tablet afirmasi yang telah dipinjamkan oleh pihak sekolah. 
Pada tahap pengamatan, tercatat bahwa guru sudah benar-benar dapat memanfaatkan tablet afirmasi dalam meningkatkan kompetensi guru menggunakan media pembelajaran daring.

Adapun data kompetensi guru menggunakan media pembelajaran daring tersebut dapat dilihat pada tabel berikut.

Tabel 3. Kompetensi Guru dalam Penggunaan Media Pembelajaran Daring pada kegiatan Siklus II

\begin{tabular}{lccc}
\hline & $\begin{array}{c}\text { Media online yang } \\
\text { pernah digunakan oleh } \\
\text { guru }\end{array}$ & $\begin{array}{c}\text { Media pembelajaran } \\
\text { yang digunakan oleh } \\
\text { guru dalam proses } \\
\text { BDR }\end{array}$ & $\begin{array}{c}\text { Media } \\
\text { Pembelajaran yang } \\
\text { telah dikuasai oleh } \\
\text { guru }\end{array}$ \\
\hline WhatsApp & $100 \%$ & $100 \%$ & $100 \%$ \\
Google Classroom & $21 \%$ & $66 \%$ & $93 \%$ \\
Google Form & $17 \%$ & $48 \%$ & $86 \%$ \\
Telegram & $10 \%$ & $31 \%$ & $62 \%$ \\
Zoom & $14 \%$ & $86 \%$ & $100 \%$ \\
\hline
\end{tabular}

Pada tahap refleksi ini diketahui bahwa hampir semua guru telah menguasai media pembelajaran google classroom dan google form, pada proses belajar mengajar guru dan siswa menggunakan google classroom, pada saat penilaian harian guru menggunakan google form.

Guru juga sudah menguasai aplikasi zoom dalam proses pelatihan/ sosialisasi, workshop atau webinar. Semua guru telah mahir dalam mengikuti zoom meeting dan pada saat prosesnya berlangsung guru dapat mengaktif dan noanaktifkan video, dan suara juga sudah bisa memberikan komentar di menu chat. Peserta didik juga hampir semuanya telah mengikuti belajar dari rumah, meskipun ada $7 \%$ siswa yang tidak mengikuti kegiatan belajar dari rumah yang dikarenakan memang siswa tersebut tidak memiliki ponsel, dan tidak ada jaringan.

Mengacu pada UU Nomor 14 Tahun 2005 yang selanjutnya diatur dalam Peraturan Pemerintah Nomor 19 Tahun 2005 menjelaskan bahwa guru harus memiliki empat kompetensi, yaitu kompetensi pedagogik, kepribadian yang baik, berjiwa sosial dan profesional dalam disiplin ilmunya (Rayuwati, 2020). Para guru senantiasa diharapkan untuk siap dalam melakukan tugas dan kewajibannya dalam rangka mencerdaskan kehidupan bangsa melalui bidang pendidikan (al Maidah et al., 2017). Sebagai pendidik, guru juga dituntut untuk menguasai semua kompetensi agar peserta didik meneladaninya. Selanjutnya seorang guru juga dituntut memiliki keahlian yang menyeluruh tidak hanya dari aspek pengetahuan, aspek sikap dan juga pada aspek perilaku positif yang tak dapat dipisahkan dalam kehidupan yang juga saling mempengaruhi antara aspek satu dengan aspek lainnya (Musfah, 2015). Dalam proses pembelajaran hendaknya guru menjalin komunikasi yang aktif dan mengembangkan siswa, sehingga keberadaan guru tidak hanya menyampaikan materi (Puspitasari et al., 2020).

\section{SIMPULAN}

Penelitian tindakan sekolah ini merupakan solusi bagi sekolah saat menghadapi proses belajar dari rumah (BDR) yang dilakukan sesuai dengan 
instruksi dari pemerintah setempat yaitu Gubernur Kepulauan Riau tertanggal 16 Maret 2020 Nomor 440/ 449/DISDIK-ET/2020, tentang ditiadakannya Kegiatan tatap muka di sekolah selama pandemi berlangsung dan kegiatan belajar mengajar dilaksanakan dari rumah secara daring.

Dengan peralihan sistem mengajar guru secara tatap muka menjadi daring secara tiba-tiba menjadi suatu permasalahan dimana media pembelajaran yang digunakan akan berubah. Dengan keterbatasan ilmu pengetahuan dan gawai guru yang memiliki keterbatasan kapasitas maka peneliti sebagai pemimpin di sekolah ini memberikan peminjaman tablet afirmasi dan memfasilitasi kegiatan workshop pemanfaatan tablet afirmasi dalam penggunaan media pembelajaran daring bagi siswa di SMA Negeri 3 Kundur. Setelah dilaksanakannya kegiatan workshop semua guru telah menggunakan google classroom sehingga proses belajar dari rumah sudah berjalan lancar. Para guru juga sudah menggunakan google classroom dalam proses penilaian harian dan ada sebagian guru yang menggunakan telegram. Dan setelah kegiatan workshop guru juga sudah bisa menggunakan aplikasi zoom dengan baik, sehingga banyak guru yang mengikuti pelatihan online melalui zoom.

\section{DAFTAR PUSTAKA}

Afnibar, \& Fajhriani, D. (2020). Pemanfaatan WhatsAPP sebagai Media Komunikasi Kegiatan Belajar ( Studi terhadap Mahasiswa UIN Imam Bonjol Padang ). Al-Munir: Jurnal Komunikasi Dan Penyiaran Islam, 11, 70-83.

al Maidah, A., Setyosari, P., \& Kuswandi, D. (2017). Pengembangan bahan ajar tematik cetak semi digital berbasis multiple intelligences untuk siswa kelas I SD. Seminar Nasional Teknologi Pembelajaran Dan Pendidikan Dasar 2017 , 11-16.

Barni, D., Danioni, F., \& Benevene, P. (2019). Teachers' Self-Efficacy: The Role of Personal Values and Motivations for Teaching. Frontiers in Psychology, 10. https://doi.org/10.3389/fpsyg.2019.01645

Faiz, A., \& Kurniawaty, I. (2020). Konsep Merdeka Belajar Pendidikan Indonesia Dalam Perspektif Filsafat Progresivisme. Konstruktivisme: Jurnal Pendidikan Dan

Pembelajaran. https://doi.org/https://doi.org/10.35457/konstruk.v12i2.973

Firman, F., \& Rahayu, S. (2020). Pembelajaran Online di Tengah Pandemi Covid19. Indonesian Journal of Educational Science (IJES), 2(2), 81-89. https://doi.org/10.31605/ijes.v2i2.659

Habibah, R., Salsabila, U. H., Lestari, W. M., Andaresta, O., \& Yulianingsih, D. (2020). Pemanfaatan Teknologi Media Pembelajaran di Masa Pandemi Covid-19. Trapsila: Jurnal Pendidikan Dasar, 2(02), 1. https://doi.org/10.30742/tpd.v2i2.1070

Mahmud, T. P. (2008). Penelitian Tindakan Kelas.

Mandailina, V., Syaharuddin, S., Pramita, D., Ibrahim, I., \& Haifaturrahmah, H. (2021). Pembelajaran Daring Dalam Meningkatkan Motivasi dan Hasil Belajar Peserta Didik Selama Pandemi Covid-19: Sebuah Meta-Analisis. Indonesian Journal of Educational Science (IJES), 3(2), 120-129. https://doi.org/10.31605/ijes.v3i2.955 
Mockler, N. (2013). Teacher Professional Learning in a Neoliberal Age: Audit, Professionalism and Identity. Australian Journal of Teacher Education, 38(10). https://doi.org/10.14221/ajte.2013v38n10.8

MR, S. (2021). Drs. H. Samhudi MR., M.Pd.I Pengembangan Media Pembelajaran. Jurnal Ilmiah STAI KH. ABDUL KABIER, 1(1), 146-163.

Musfah, J. (2015). Peningkatan Kompetensi Guru melalui Pelatihan dan Sumber Belajar Teori dan Praktik. Prenadamedia Group Jakarta.

Muslihudin, M. (2016). Meningkatkan Kemampuan Guru Dalam Pembuatan Media Pembelajaran Melalui Kegiatan Workshop. P2M STKIP Siliwangi, 3(2), 51. https://doi.org/10.22460/p2m.v3i2p51-58.627

Myori E.D, Krismadinata, D. (2019). Peningkatan Kompetensi Guru dalam Penguasaan Teknologi Informasi dan Komunikasi melalui Pelatihan Pengembangan Media Pembelajaran Berbasis Android. JTEV (Jurnal Teknik Elektro Dan Vokasional), 5(2), 102-109.

Nadlir. (2014). Urgensi Pembelajaran Berbasis Kearifan Lokal. Jurnal Pendidikan Agama Islam, Volume 02, 300-330.

Puspita, R. et. al. (2020). Pemanfaatan Youtube Sebagai Media Pembelajaran Bagi Mahasiswa di Tengah Pandemi Covid-19. 1-15.

Puspitasari, W. Fajar., Martaningsih, S. Tutur., \& Sukardi, Sukardi. (2020). Peningkatan Motivasi Dan Hasil Belajar Pembelajaran Daring Pada Siswa Kelas 1 SD Negeri Turi 3 Melalui Media Powerpoint. Prosiding Pendidikan Profesi Guru, Fakultas Keguruan DAan Ilmu Pendidikan, Universitas Ahmad Dahlan, 1344-1352.

Ramdani, A., Jufri, A. W., \& Jamaluddin, J. (2020). Pengembangan Media Pembelajaran Berbasis Android pada Masa Pandemi Covid-19 untuk Meningkatkan Literasi Sains Peserta Didik. Jurnal Kependidikan: Jurnal Hasil Penelitian Dan Kajian Kepustakaan Di Bidang Pendidikan, Pengajaran Dan Pembelajaran, 6(3), 433. https://doi.org/10.33394/jk.v6i3.2924

Rayuwati, R. (2020). How educational technology innovates distance learning during pandemic crisis in remote areas in Indonesia? International Research Journal of Management, IT and Social Sciences, 7(6). https://doi.org/10.21744/irjmis.v7n6.1032

Reflianto, \& Syamsuar. (2018). Pendidikan dan Tantangan Pembelajaran Berbasis Teknologi Informasi di Era Revolusi Industri 4.0. Jurnal Ilmiah Teknologi Pendidikan, 6(2), 1-13.

Sa'bani, F. (2017). Peningkatan Kompetensi Guru dalam Menyusun RPP melalui Kegiatan Pelatihan pada MTs Muhammadiyah Wonosari. JURNAL PENDIDIKAN MADRASAH: (Journal of Madrasah Education), 2(1), 13-22.

Sadewo, Y. D., \& Purnasari, P. D. (2019). PENINGKATAN HASIL BELAJAR DAN SELF EFICACY SISWA MELALUI MODEL PEMBELAJARAN CAROUSEL FEEDBACK DAN SHOWDOWN PADA MATA PELAJARAN KEWIRAUSAHAAN (Studi Kasus Pada SMA Negeri 1 Bengkayang). Sebatik, 23(2), 522-527. https://doi.org/10.46984/sebatik.v23i2.809

Sadikin, A., \& Hamidah, A. (2020). Pembelajaran Daring di Tengah Wabah Covid-19. Biodik, 6(2), 109-119. https://doi.org/10.22437/bio.v6i2.9759 
Sutirman. (2013). Media \& Model-Model Pembelajaran Inovatif. Graha Ilmu Yogyakarta.

Tarlia Nalar, V. (2020). PTK Penggunaan Gadget dalam Permainan Quizziz untuk Meningkatkan Hasil Belajar Kimia Kelas X.MIPA Semester Genap Tahun Pelajaran 2019/2020.

Ulfah Fajarini. (2014). Peranan Kearifan Lokal Dalam Pendidikan Karakter. Jurnal Sosio-Didaktika: Social Science Education Journal.

Wardani. (2007). Penelitian Tindakan Kelas.

Yuangga, K. D., \& Sunarsi, D. (2020). Pengembangan Media dan Strategi Pembelajaran Untuk Mengatasi Permasalahan Pembelajaran Jarak Jauh Di Pandemi Covid-19. ( Kharisma Dan Denok, 2020 ), 4(3), 51-58. 